part in this work; meanwhile, however, it also aims at arousing an interest among British men of science in the potential value of Esperanto for the exchange of scientific information and at creating in Great Britain a nucleus of workers who are themselves adepts in the use of the language for scientific purposes. Several of its members are engaged in the compilation of technical vocabularies in various fields-an essential task inasmuch as (though Esperanto has been in use for general purposes for sixty years) there is as a result of the interruption of normal communications in recent times a considerable need for the standardization of many new technical terms which have come into use during this period. The Association has also made informal contacts with Unesco and other international organisations with regard to the whole question of international language. Since its inception in February 1947, the Association (which has an advisory panel of distinguished workers in various branches of science) has held a number of meetings at University College, London. Business proceedings are conducted in English, but technical papers are read and discussed in Esperanto. Membership of the Association is open to all who are interested in the application of Esperanto to science and technology, whether professionally occupied in these fields or not. The president is Dr. J. C. Flugel, of University College, London, and the honorary secretary, Mr. E. D. Durrant, of 15 Beaufort Road, Reigate, Surrey.

\section{Vitamin D Assay}

Althovgr specification for the assay of vitamin $\mathrm{D}_{2}$ by the chick method exists (London: British Standards Institution : B.S.S.911) there is none pertaining to assay on rats, the test animals used in many different laboratories. The Society of Public Analysts and Other Analytical Chemists, and the Society of Chemical Industry therefore set up a joint committee to determine "the fiducial limits that might reasonably be expected in biological assays of vitamin D using rats". British organisations employing this technique were asked to submit statements and opinions based on their own experience, and as a result of the information so collected the joint com. mittee has now issued the following statement : "In the absence of any special circumstances, it is reasonable to expect that assays of vitamin $D$ by the rat method in normal commercial practice should have fiducial limits (calculated to a probability level of 95 per cent) not wider than 60-170 per cent"; and the opinion is expressed that "the result of any assay conforming to these limits should be a com. mercially acceptable estimate of the true potency of the material assayed". Fuller details are being presented by the committee in the Analyst and in Chemistry and Industry.

\section{Geophysics in Finland}

GEOPHYSICAL studies in Finland on truly scientific lines started early in the eighteenth century, a movement in which an 'invitation' of date 1723 from James Jurin, secretary of the Royal Society, to co-operate in meteorological observation, played a part. An account of the early history of Finnish geophysical studies appeared in 1935 in the first issue of a journal, Geophysica, published by the Geophysical Society of Finland, a body founded in 1926. Papers are read at its meetings; but the Society is not in the main a publishing body. Geophysica No. 1 (financed by a grant from lottery funds) included, however, three general articles besides the historical summary, and also thirty-six pages of summaries (by the authors) of Finnish geophysical papers published during 1930-34, giving a view (though incomplete) of the then recent Finnish activity in the subject. This view is now extended by the appearance in 1947 of Geophysica No. 2, which, like No. 1, is written wholly in English and German. Apart from two short articles on the Finnish Geodetic Institute, 1918-38, and the Isostatic Institute (subsidized, except during the War, by the International Association of Geodesy), the volume is devoted to authors' summaries of Finnish geophysical literature during the period 1935-44. An improvement on No. 1 is the inclusion of alphabetical lists of authors under five subject-headings, which makes the volume very convenient for reference in searching for any recent work done in Finland on these topics. The volume well indicates the extensive and valuable work done in geophysies in Finland during ten troubled years.

\section{Portable Barometer}

A PORTABLe barometer made by the well-known clockmaker Daniel Quare (1649-1724) has been lent by Mr. R. Meyrick, of Corbridge-on-Tyne, to the Science Museum, South Kensington. The barometer is an early domestic form of the instrument, in which the tube and cistern are enclosed in a fluted walnut case carried on four metal feet. Thus the instrument can stand on a table, though a ring is also provided for hanging it against a wall. This barometer was the first designed for portability, having been made by Daniel Quare to his own patent specification of 1695. It uses a cistern with a flexible leather bottom which can be compressed by means of a screw so as to fill the barometer tube with mercury and thus avoid the risk of damage when the barometer is moved. To reduce this risk still further, there is a constriction near the top of the tube, to retard the flow of the mercury and thereby reduce the impact of the column on the upper, closed end of the tube. The instrument has a weather scale very similar to that still used on domestic barometers.

\section{An Interesting Hemipterous Insect from New Zealand}

IN the first volume of Dominion Museum Records in Entomology (Wellington, N.Z.), June 1948, p. 63, Carl J. Drake and J. T. Salmon contribute a short paper entitled "A Second Xenophyes from New Zealand" Under the name of Xenophyes forsteri, the authors describe a new species of the small and littleknown family Pelorididæ from New Zealand. The family, it may be added, is also known from southern Argentina, Patagonia, Australia and Tasmania. It provides, therefore, an additional link in the evidence from other sources of a direct land connexion between the South American and Australasian continents. Only seven species grouped under three genera of Pelorididæ are at present known. What little biological evidence there is available indicates that its members feed largely, or wholly, on mosses, and inhabit damp situations. The family was originally placed in the Hemiptera - Heteroptera and, since the antennæ are concealed from view, it was relegated to the series Cryptocerata. Recent research, however, indicates that its affinities lie with the suborder Homoptera and that it represents a separate and new series named by Myers and China in 1929 the Coleorrhyncha. This view is now generally accepted by most students of Hemiptera. The species are all 
very small creatures the hind wings of which are vestigial or absent. The tegmina occur in probably all the species in two forms, macropterous and brachypterous, although both these types have not yet been found in all cases.

\section{The Solar Apex}

Mr. O. R. WAIKEy has examined the literature on the position of the solar apex (Mon. Not. Roy. Astro. Soc., 106, No. 4 ; 1946). Table 1 shows the marked divergences in the positions determined from 1933 to 1941. Mr. Walkey uses as his basis Moore's "Catalogue of Radial Velocities" (Pub. Lick Obs., 18; 1932) and Boss' "General Catalogue" (Carnegie Pub., No. 468 ; 1937). It is suggested that the divergences just referred to may be partly due to rotation in a probable local cluster which leavens the allowance made for galactic rotation-a view to which some support is given by the increased declination in the apex with increased magnitude of the stars used. Mr. Walkey believes that our ignorance of the actual peculiar motions of the stars, and the consequent assumptions required to fill this gap in our knowledge, may undermine "the refined mathematical edifice built thereon". Using the two catalogues mentioned, he considers the sense alone of their respective motions, whether reflecting "pro"-solar motion, or the reverse-"con". In this way he by-passes assumptions for distance (for cross-motions), etc., and also the general assignment of arbitrary limits for acceptable motions. A full explanation of the method appears in the paper, to which reference must be made for details of the method; Mr. Walkey states that the method is a development of that mentioned by Russell, Dugan and Stewart in "Astronomy", vol. 2. As a result of his investigation, involving 40,720 star motions, Walkey's conclusions are as follow: position of solar apex, 1900.0; R.A. $270 \cdot 2^{\circ} \pm 0 \cdot 3^{\circ}$, Dec. $+28 \cdot 7 \pm 0 \cdot 5^{\circ}$. The solar velocity of approach was found to be $20.5 \pm$ $0.6 \mathrm{~km}$. $/ \mathrm{sec}$., its galactic planar component being $19.0 \mathrm{~km} . / \mathrm{sec}$. and the normal $7.75 \mathrm{~km}$./sec.

\section{Metal Caps for Test-tubes}

We have received from Messrs. Oxo, Ltd. (Thames House, Queen St. Place, E.C.4), samples of metal caps for test-tubes. These caps have been used for some time in their laboratories, and Messrs. Oxo offer to supply them free of charge to other laboratories which ask for them. The caps are intended as a substitute for cotton wool plugs, and Messrs. Oxo claim for them the following advantages : test-tubes of media fitted with the caps remain sterile for long periods; there are no fibres to contaminate the media; tubes fitted with the caps can be sealed with 'Cellophane'; the caps can be labelled with an ordinary pencil and this labelling withstands autoclaving; they are easily removed and replaced and do not stick to the mouths of the tubes; the caps last a long time and can be cleaned by boiling in 0.5 per cent caustic soda, followed by rinsing and drying. The caps appear to be made of an aluminium alloy and are supplied in three sizes to fit standard test-tubes with outside diameters of $\frac{5}{8}, \frac{3}{4}$ and 1 in.

\section{Rare and Historic Maps}

Mr. Francis Edwards, 83 Marylebone High Street, London, W.1, has issued a catalogue (No. 692) of maps and atlases of the British Isles from the sixteenth to the nineteenth centuries which contains several items of unusual interest. There is a first edition of Camden's "Britannia" with 57 doublepage maps, and also a copy of Collins' "Coasting Pilot" of 1693 with 48 maps. Perhaps more noteworthy are several copies of different editions of Speed's atlas, including the rare fully-coloured one, and a first edition of Saxton's atlas of England and Wales. The catalogue also lists a copy of that rarest of all sea atlases, "Arcano del Mare" of Robert Dudley, Duke of Northumberland, with 133 maps, and plans and diagrams.

\section{Geology in Scotland: Swiney Lectures}

THe first half of the course of Swiney Lectures on geology are being delivered (December 6-17) by Dr. Douglas A. Allan, director of the Royal Scottish Museum, at the Museum itself in Chambers Street, Edinburgh. The general title covering the twelve lectures is "The Geology and Scenery of Scotland". This is the first time that Swiney Lectures, which are under the direction of the British Museum (Natural History), have been given outside London, and $\mathbf{M r}$. N. B. Kinnear, director of the Museum, presided at the opening lecture. The last six lectures will be delivered at the same place at 5.30 p.m. on Mondays, Wednesdays and Fridays during January 17-28, 1949.

\section{Announcements}

Prof. Ernst Gaumane, of the Federal Technical College, Zurich, has been elected correspondant for the Section of Botany of the Paris Academy of Sciences, in succession to Dr. A. F. Blakeslee, who has been elected a foreign associate of the Academy.

Prof. E. G. CULLWICK, director of the Electrical Research Division, Research Defence Board, Ottawa, will be the first occupant of the new Watson-Watt chair of electrical engineering at University College, Dundee.

Dr. J. L. B. Cooper, of the Department of Mathematics, Birkbeck College, University of London, has been appointed to the University readership in mathematics tenable at the College.

A SERIES of four sessions on the "Educational and Social Significance of the Land" has been arranged by the Association of Agrieulture and the University of London Institute of Education, to be held at the latter's headquarters in Malet Street, London, W. C.1. The first session has already been held and the remaining three will be at 10 a.m. on December 11, and February 5 and 19. At each session two lectures of one hour's duration will be delivered, and emphasis will be laid on teaching methods in the middle forms of secondary schools. Admission is 1s. per session or 2s. $6 d$. for all four, and further details may be had on application to the general secretary, Association of Agriculture, Abbey House, Victoria Street, London, S.W.I.

A sERIEs of three Christmas Lectures, especially adapted for a juvenile audience of from twelve to seventeen years of age, will be given in the Royal Photographic Society's House, at 16 Princes Gate, London, S.W.7, on December 29, 30 and 31, 1948. A special house exhibition, comprising Nature sub. jects, is being arranged by Mr. Oliver Pike to coincide with the lectures. The lecturers and subjects will be as follows: "The Chemistry of the Process", by Dr. H. Baines ; "Formation of the Image and Making the Negative and Print", Part I, by Mr. K. H. Gaseltine, and Part 2 the next day. Admission will be free but by ticket only, obtainable on application to the Secretary of the Society at the above address. 